\section{Rivals clash over plans to take science to London public}

\section{David Adam, London}

Researchers planning an $\mathfrak{E} 8$ million (US\$11 million) science communication centre at London's Science Museum have been wrong-footed by a separate proposal to open a similar centre, more than a year earlier and only a few miles away.

Recent high-profile controversies over such issues as the risks posed by bovine spongiform encephalopathy and genetically modified crops have made science communication a big issue in Britain. Both initiatives aim to engage scientists in a dialogue with the public.

Later this month, officials at the Science Museum will announce plans to build a new venue for people to meet scientists and discuss controversial issues such as cloning and animal experiments. The building will feature lecture and discussion rooms, as well as informal social facilities. The British Association for the Advancement of Science, which promotes science communication and education in the United Kingdom, will move into the building when it opens in 2003.

Meanwhile, the Royal Institution, an independent organization also involved in science communication, is planning to open a 'science media centre' early next year. Susan Greenfield, director of the Royal Institution, says the centre will help scientists discuss their work and its risks with the public by acting as a conduit to journalists. She plans to put a 'science spokesperson' in charge of the centre with the authority to speak to the press on behalf of media-shy colleagues.

But some scientists behind the museum's project say Greenfield failed to consult them about the Royal Institution's plans - and that, as a result, both are trying to do much the same thing.

"It is unfortunate that there was not sufficient prior consultation about the Royal Institution's media centre in light of the already well-developed plans for the new Science Museum building," says Colin Blakemore, chair-elect of the British Association.

Others are also critical of the Royal Institution's plans. Aspects of the proposals, such as a one-stop science spokesperson to comment on everything from AIDS to astronomy, are "unwelcome and unworkable", says one official of a leading scientific society.

Greenfield admits that she could have consulted more widely, but insists there is room for both projects.

\title{
Museum director quits over Smithsonian restructuring
}

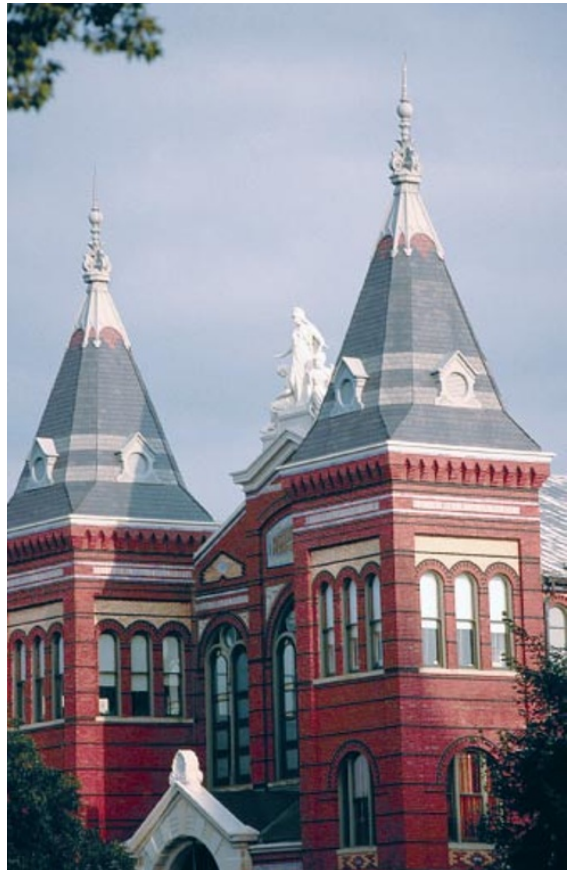

Changes due: plans include separating the management of research from that of exhibitions.

\section{Corie Lok, Washington}

Plans to streamline research at the Smithsonian Institution, the world's largest museum complex, remained steeped in controversy last week with the resignation of the director of its National Museum of Natural History.

Robert Fri quit his post at the museum, which contains the institution's largest research operation, apparently in protest at the proposed restructuring.

In an effort to defuse the mounting tension between management and scientists over its plans, the Smithsonian's administration will this week name a 15-member committee to advise it on the details of the restructuring.

The panel will be chaired by Jeremy Sabloff, director of the University of Pennsylvania Museum of Archaeology and Anthropology in Philadelphia. It will feature members drawn from both inside and outside the Smithsonian.

The institution's governing Board of Regents voted to set up the advisory panel last month (see Nature 411, 119; 2001), after Smithsonian secretary Larry Small and science undersecretary Dennis O'Connor were criticized for pushing their restructuring plan through without consulting scientists.

According to Smithsonian officials, that plan has now been put on hold, pending the advisory panel's recommendations. But the institution's scientists remain sceptical of the panel's influence and believe that parts of the plan, including the separation of the management of research from that of exhibitions, are almost certain to be adopted.

In his resignation statement Fri said: "It seems likely that the research and collections responsibilities of the museum will report directly to the undersecretary for science." Restructuring the museum "will require the leadership of a management team committed to pursuing its success over the long haul", he continued. "I do not feel that I can make that commitment enthusiastically." Fri will stay on as director until the end of September.

According to Brian Huber, a palaeobiologist at the National Museum of Natural History and chair of the Smithsonian's academic senate, the separation of research and exhibits would jeopardize the Smithsonian's mission of increasing and disseminating knowledge. Exhibits require input and interaction with scientists, he says.

Such a separation was discussed at a meeting of the Board of Regents last month and is seen as "a good idea", according to board member Manuel Ibanez, a retired biologist and former president of Texas A\&M University in Kingsville. Bringing research under one director could increase efficiency without preventing interaction between scientists and exhibit staff, he says.

But no final decisions were made on the proposal and the board remains open to the advisory panel's recommendations, according to Hanna Gray, another board member, a historian and former president of the University of Chicago.

Huber says that an ad hoc group of scientists, of which he is part, is putting together its own restructuring proposal and will submit its plan to the advisory panel later this summer.

Sources at the Smithsonian say that Rita Colwell, director of the National Science Foundation, was invited to co-chair the advisory panel with Sabloff but declined to do so. Colwell would not comment.

Meanwhile, the institution's restructuring plans, which must be approved by the Congress, came under attack on another front, with two Maryland senators writing to Small protesting over the proposed closure of the Smithsonian Center for Materials Research and Education in Suitland, Maryland. Small backed down last month from closing the Conservation and Research Center in Front Royal, Virginia, in the face of opposition from researchers and Virginia congressmen. 